\title{
On the Importance of Positive Emotions in College English Teaching and Learning
}

\author{
Yuanzhen Peng \\ English Department \\ North China Electric Power University \\ Baoding City, People’s Republic of China \\ ohamster@126.com
}

\begin{abstract}
This paper attempts to analyze how to arouse students' positive emotions in the process of college English teaching and learning mainly based on the writer's own personal observations and esperiences . Students and teachers form an integral whole in the process. They have impact on each other. Therefore, teachers' positive emotions cannot be ignored either.
\end{abstract}

Keywords-positive emotions; teachers; students

\section{INTRODUCTION}

Learning is regarded as an interesting and rewarding experience if students gain confidence and have a sense of achievement in the process. Teaching is considered as a rewarding and enjoyable experience if teachers see students' activeness and commitments in the process. One Friday afternoon, when I saw the freshmen's tired expressions on their faces, I myself was reluctant to speak loudly. Was I supposed to refresh them? And how? We are not supposed to get energetic on Friday afternoons regardless. During the break, I asked the students why they looked so exhausted. They looked up at me and were eager to give the explanation: they were occupied with reserving train tickets. The tickets would be sold out quickly. I got to know they longed to go back home. Although not totally refreshed, most of the students tried hard to be focused on the class. Suppose another case. If I had blamed them for their inactiveness in class, they would not have bothered to listen to my lecture any more. They would just have scheduled their journey back home in their mind, not caring about what I saying, let alone the task I assigned them to do.

The class is undoubtedly a platform for teachers and students to communicate knowledge, ideas and thoughts. Nevertheless we cannot be ignorant of the fact that teachers and students are human beings and they have certain feelings during the process of communication of knowledge, ideas and thoughts. Both of them are not machines, taking data and spitting out data. Moreover, whether they have positive emotions or not could have a strong impact on the results and effects of the communication. The purpose of this paper is to explore the good effects brought about by positive emotions of both the teachers and students in the process of college English teaching and learning.

\section{IMPORTANCE OF POSITIVE EMOTIONS IN LEARNING}

Language learning requires lots of time, discipline, and commitment. Without being given encouragement, students would feel more frustrated and depressed in the acquisition of
English. According to Noam Chomsky, Universal Grammar in each child's brain enables them to acquire language from birth. But language learners do not absorb everything they are exposed to. Their motives, needs, attitudes and emotional states influence how much they can take in and how well they can perform (Duly et al, 1982:45). The "emotional states" is one of the factors to explain why some students are more inclined to commit time and energy to English study. Imagine a student learns English under pressure from parents. Even if he can get a high score in examinations, the experience of English learning prevents him or her from going ahead or moving forward. The learner, to some extent, has made a success. But if he or she is asked about how he or she feels about English learning, the learner is most likely to shake his head and recall the tears and sweats. It seems to be a bitter, though rewarding, experience, rather than an interesting and delectable one. Only if one day, the learner finds it useful to speak English when being abroad, he or she would not regret the time and efforts devoted to the task. Hopefully, English would not sound like a nightmare.

\section{A. Characteristics of Chinese Students}

In order to find out efficient ways to cultivate Chinese students' eagerness to study English, we need to analyze their characteristic that cannot certainly be ignored.

Firstly, levels of English proficiency differ from student to student. There are usually fifty students in a College English class. They come from different parts of China and from different family backgrounds. Students from the eastern parts enjoy a higher quality in English education in high school and in primary school. They start learning English since the third year in primary school or some even start when they are in the kindergarten. They have a clear pronunciation and a good intonation. But some students are from the western parts. They have difficulty in pronouncing words and reading sentences aloud, let alone speaking English in class. There are one or two students who are especially excellent or terribly poor. Generally speaking, students are grouped into Band One classes and do not have had special training in listening. At the beginning of the semester, all of the freshmen told me the same story. They did not have listening classes in high school. They were frustrated with College English study because the teacher spoke so much English in class and the listening exercise part sounded impossible to cope with. Students made explanations because they couldn't answer questions in class.

Secondly, different students have different personalities. Some are active and willing to communicate with their peers 
and teachers. They usually have a smiling face and want to ask the teacher for advice about how to make progress in college study. These students are inclined to study hard in a positive mood and can reap the benefits of English learning after a relatively short period. Some students are silent but they make efforts themselves, despite the same difficulties they encounter as others. They tend to sit at the back of the classroom or in the middle but not in the front. Still there are some students who just let their disadvantages be.

Thirdly, students' ages range from seventeen to nineteen. For most of them, it is the first time to be far away from home and to deal with life and study by their own. In addition to English, they have mathematics, physics and politics to handle. They expect to be treated as adults: be respected and be responsible.

Last but the least, students' past experience in English learning has to be taken into account. After several years' intense preparation for the college entrance examination, students are accustomed to working hard silently and individually. They are used to reading materials and doing exercises. What's more, the majority of the students care more about results of examinations, which determine whether they will be successful or not in college. Therefore, English is more taken as a subject rather than as a language or a means to communicate with people all over the world. It explains why students are reluctantly involved in English discussions in class.

\section{B. Ways to Cultivate Positive Emotions}

In view to the above characteristics mentioned about Chinese students in College English classes, we come up with some approaches to cultivating in them as many positive emotions as we can through encouragement and communication with them.

Communication-in-class between teachers and students is critical in establishing a good relationship between them. English is a course of a foreign language. Language carries thoughts and ideas. It is hard to imagine an English class without interaction between the teacher and the students. Without communication, students know little about the teacher and neither do the teacher. For the first time I met my students in class, I usually gave a brief introduction about myself. I told them my hobbies like reading books, travelling and doing sports. Later in discussions in class, students were open to talk about their ideal job because they thought they could travel around the world or have much free time, which corresponded to my personal ideal job. That's to say, we find something common and tend to be more open to communicate. Moreover, when some students said they would like to take advantage of their spare time to do sports and traveling, I directly told them I liked their ideas. They felt confident not only about their English but also about their ideas and values, which are appreciated by their teacher in front of the whole class. Brief oral presentations after pair or group discussions are good chances for students to practice oral English and also equally important opportunities to communicate with their teacher. Students long to see the teacher's comments on their thoughts and feelings. If positive, the teacher is supposed to appreciate what is in their mind.
Communication-after-class cannot be ignored either, which can be carried out in our native language and frequently happen in the break. It is often teachers who take the initiative to begin the conversation. In autumn, leaves of the trees on campus looked colorful and the campus turned beautiful. I took some pictures and showed them to my students during the break. I suggested that they enjoy the beauty around them. Besides, I asked about their other courses and businesses in daily life. They feel more and more at ease in class due to the talks after class. They care about what is being taught in class and have a desire to be involved in activities.

Priority is given to the comprehension of texts and the study of language points. A\&Q form, asking-and-answering questions, is preferred by English teachers. The focus is to pick out the most suitable student for a certain question. That's to say, who is fit to be called his or her name to answer the question. If you are sure that a student is able to translate a sentence from Chinese to English, ask him or her to do that, which offers him a good chance to feel good about himself. For example, I would ask students who has a clear pronunciation and a loud voice to read the paragraphs aloud in class. They tend to feel proud to read. One thing registers that if the student pronounces some words incorrectly, we need to wait patiently for him or her to finish and then point out the error. I once interrupted them when a pronunciation mistake occurred and found out that the more I pointed out the mistakes, the more nervous they sounded. When doing compound dictations, I waited for anyone who was brave enough to look up. If nobody was self-confident enough, I usually asked them to exchange ideas first. At the same time, I walked around the classroom to spot the one who performed well in the listening task. Once I found the one, I would invite him or her to write down the words he or she had heard. It turned out it was the one who could always do the best in listening. The higher the expectations are, the better students tend to perform in class and in their assignments. It is the best way to reduce the feeling of frustration. If a question is beyond the student, the question is useless except in lowering the student's confidence and interest. Worse still, the student would feel it is a matter of face. He or she feels he or she loses face. English turns to be a nightmare. The English teacher turns to be resented. Therefore, it is essential for the teacher to have a good evaluation of all of the students' English level in order to inject confidence into them by asking them to answer the questions they are capable of and sure of. The happiness brought about by leaving a good impression on classmates and the teacher arouses their further interest to learn more and answer more. Therefore, when students are finishing exercises either of listening, reading or of translation, it is useful for teachers to walk into the students to have a look at how they have accomplished the task. It is a skill to select the right student for the right question.

How to give encouraging feedback on their written work is of great importance as well, which includes their assignment after class and their written task in class. At the beginning of each class students are required to dictate the words they have learned last time. Once a student with good records wrote only a few words and he wrote the reason after the words that he was late for a couple of minutes. I wondered whether to ask him to be punctual or to ask him why he was late. Thinking it 
over, I finally wrote: Yes, I saw it. When the sheets of paper were handed out, I registered that the boy was smiling, holding his sheet in his right hand. He must have read my words. The story reveals that blaming and pressing the teenage students is not as effective as writing feedback as they are friends.

\section{Effects of Positive Emotions on English Acquisition}

Interest drives students to learn more efficiently. Interest may come from the subject itself or from the teacher or from the competition among peers. The purpose of cultivating students' positive emotions is to arouse their interest in English learning. They feel like learning English instead of being forced to study, which is agony. They will devote time and energy to the accumulation of words and the improvement of listening. They will follow the advice given by the teacher to promote the level of their English. In addition, positive emotions help students to overcome difficulties they are confronted with in English learning. They are encouraged to move on despite the hardship. Confidence they get in class by answering certain questions gives them the strength to move ahead. There will be fewer complaints, less laziness, less fatigue and less frustration.

The atmosphere of the class is likely to be influenced by the relationship between the teacher and students. There are many interactive activities in class. How students respond to questions and how the teacher responds to students' answers have a direct impact upon the class's atmosphere and their future relationship. If the atmosphere and relationship are friendly, students feel at ease in the English class and they would like to be involved in as many activities as possible. As we know, active participation in class is of great significance for students to be exposed to the English environment and get accustomed to the way of English thinking. It is perhaps the only time students can use English in their current life. Thanks to the sense of belonging, students attach importance to English and English study. They turn to love English because of the friendly atmosphere of the English class. Students are inclined to make contributions to the class. The whole class is put in an active circle. The teacher doesn't have to divide his or her precious time with the class management. The class is all the time carried on in an efficient way. Students harvest knowledge and fun in the learning process. When the bell rings, students walk out of the classroom with a satisfied expression on their faces, which is the fruit of the class. They are bound to share their happy experience in English class.

\section{IMPORTANCE OF POSITVIE EMOTIONS IN TEACHING}

\section{A. Characteristics of College Englsih Teachers in China}

The majority of College English teachers major in English and have obtained their master degree. They have a fairly good command of the language. Most of them are females. They tend to be patient and kind toward their students. Since graduation from university, they begin their profession as an English teacher. They have the same experience as their students and will find it not difficult to communicate with them. They may share common hobbies and like the same singer or athlete. Female teachers are more considerate of students' feelings.

\section{B. Factors that Affect Teachers' Emotions}

Teachers are living in their context. They are under the influence of the circumstances. In our university, there is a system where students can log and make comments on their teachers and their classes. Teachers are not only under the supervision of the institution but also they are graded by their students. That's to say, teachers teach courses under certain pressure.

There is fierce competition among teachers themselves. They are ranked according to the percentage of their students who pass the band four or band six tests. Teachers' performance is determined by the scores students achieve in the nationwide tests. If students follow their advice and make a great progress in study, teachers would be delighted and willing to commit more time and energy to the course.

One afternoon I had to explain the same stuff to different classes. My loud voice turned smaller and dull. Twenty or thirty minutes later some students yawned in class. It was difficult for them to concentrate on what was being discussed. Teachers' enthusiasm brings about students', and at the same time, teachers' fatigue seems to bring about students' as well. The personal experience reveals that teachers' voice and facial expressions as well impose impact on students' feelings. In return, students' facial expressions and reactions to teachers' questions impose direct and strong impact on teachers' mood in class. This semester I have three classes, which have their own features. The one I like best is full of energy. Students concentrate on what is dealt with and follow me step by step. The flow of the class goes smoothly. In this case, the teacher devotes the whole being to the teaching materials. While in another class, most students are serious and inclined to keep silent. When I ask questions, they have to think about for a few more minutes. It is never an easy thing to communicate with them in English in class. I have to encourage and inspire them. I have to be patient; otherwise they haven't been prepared to answer. After class, I find it not easy to carry on the class and I am less enthusiastic about teaching because the flow of the class seldom moves smoothly. Additional time is allowed for their thinking, reasoning and struggling. Hence, the teacher is not a computer or a machine and nor the students. Despite the same teaching materials, teaching can never be simply and mechanically repeated.

\section{Effects of Positive Emotions on English Teaching}

There are more than fifty students and one English teacher in a classroom. Whether it is student-centered or teachercentered, the teacher plays an important role in the class as an independent individual. He or she is the director of the movie and also one of the leading actors or actresses. Suppose a teacher walks into the classroom frowning. Students would tend to keep silent immediately because none of them want to be a scapegoat. But if a teacher walks into the classroom smiling, students, especially those sitting in the first row, would like to smile as well and be ready to have small talks with the teacher before the class begins. In addition, the teacher's voice reveals his or her mood as well. If the teacher speaks English in a loud voice, students, especially boys, would get excited when hearing the loud voice. But if the teacher's voice is small, 
students would be murmured into sleeping, let alone their excitement and involvement.

When illustrating the usage of the phrase "be addicted to", the teacher can take advantage of examples to implement moral education. The teacher can give the example as follows: Are you addicted to smoking? The students proudly answer, "No." Then the teacher is supposed to immediately confirm their attitude by saying “Good!” The process of explaining language points can be employed to convey certain values to the students, helping them figure out what is the right thing to do when they are alone far away from their parents. If students like the teacher and the course, they tend to behave under the instruction of their beloved English teacher.

\section{CONCLUSIONS}

Now that communication occurs either in discussions or in asking and answering questions, the College English teachers have access to students' thoughts, ideas and feelings. They can find out whether students are interested in a topic or not. It is apparent that all that happens in class is bidirectional. After the analysis, some conclusions can be reached.

Firstly, teachers are supposed to bear in mind his or her students, especially their reactions and emotions. Preparation for class is not merely some planned activities or sentences. Students should be given the first priority. Teachers' love and concern can be shown towards students. Students feel the love and will love their teacher, their English class and ideally the English language.

Secondly, traditional classes can not be totally replaced by virtual classes. Students are entitled to a variety of online English classes. Some students can stick to learning and follow the schedule. But students have their individual characteristics. They may react with different responses and emotions facing the same question or the same task. Teachers need to see their facial expressions and maintain eye contact. Teachers and students can become friends. English teaching and learning is not simply the communication of knowledge.

Finally, teachers should look energetic and fresh when stepping onto the platform. Their positive emotions have the power to inject confidence and enthusiasm into students.

\section{REFERENCES}

[1] Dulay \& Burt \& Krashen, Language Two. Oxford: Oxford University Press, 1982.

[2] Hongyan $\mathrm{Hu}$, "The influence of anxiety and self-confidence on English learning,” Teaching English in China, vol.26, pp.36-41, March 2003.

[3] Kai Hu \& Shuqin Huang, College Students Psychology Development. Changsha: Hunan Science and Technology Press, 1999.

[4] Yi Wang, "Self-confidence and foreign language learning,"Modern Foreign Language, vol. 3, pp39-42, 1996. 